\title{
Nitric Oxide Amplifies Interleukin 1-induced Cyclooxygenase-2 Expression in Rat Mesangial Cells
}

\author{
Toshifumi Tetsuka, ${ }^{\ddagger}$ Dorit Daphna-Iken, ${ }^{\ddagger}$ Brent W. Miller, ${ }^{\star}$ Zhonghong Guan, ${ }^{\ddagger}$ Lisa D. Baier, ${ }^{\ddagger}$ and Aubrey R. Morrison ${ }^{\star \ddagger}$ \\ Departments of $*$ Medicine and ${ }^{\ddagger}$ Molecular Biology and Pharmacology, Washington University School of Medicine, St. Louis, \\ Missouri 63110
}

\begin{abstract}
Interleukin 1 and nitric oxide (NO) from infiltrating macrophages and activated mesangial cells may act in concert to sustain and promote glomerular damage. To evaluate if such synergy occurs, we evaluated the effect if IL-1 $\beta$ and $\mathrm{NO}$ on the formation of prostaglandin (PG) $\mathrm{E}_{2}$ and cyclooxygenase (COX) expression. The NO donors, sodium nitroprusside and $S$-nitroso- $N$-acetylpenicillamine, alone did not increase basal $\mathrm{PGE}_{2}$ formation. However, these compounds amplified IL-1 $\beta$-induced $\mathrm{PGE}_{2}$ production. Similarly, sodium nitroprusside and $S$-nitroso- $N$-acetylpenicillamine by themselves did not induce mRNA and protein for COX-2, the inducible isoform of $\mathrm{COX}$; however, they both potentiated IL-1 $\beta$-induced mRNA and protein expression of COX-2. The stimulatory effect of NO is likely to be mediated by cGMP since ( $a$ ) an inhibitor of the soluble guanylate cyclase, methylene blue, reversed the stimulatory effect of NO donors on COX-2 mRNA expression; (b) the membrane-permeable cGMP analogue, 8-Br-cGMP, mimicked the stimulatory effect of NO donors on COX-2-mRNA expression; and $(c)$ atrial natriuretic peptide, which increases cellular cGMP by activating the membrane-bound guanylate cyclase, also amplified IL-1 $\beta$-induced COX-2 mRNA expression. These data indicate a novel interaction between NO and COX pathways. (J. Clin. Invest. 1996. 97:2051-2056.) Key words: nitric oxide - cyclic GMP • interleukin 1 - cyclooxygenase $\cdot$ prostaglandins
\end{abstract}

\section{Introduction}

The free radical nitric oxide $(\mathrm{NO})^{1}$ has emerged as an important signal and effector molecule in mammalian physiology. It has been implicated to function in a variety of fundamental bi-

Address correspondence to Aubrey R. Morrison, Professor of Medicine and Molecular Biology and Pharmacology, Washington University School of Medicine, 660 South Euclid Avenue, Box 8103, St. Louis, MO 63110. Phone: 314-362-2597; FAX: 314-362-2547.

Received for publication 30 June 1995 and accepted in revised form 7 February 1996.

1. Abbreviations used in this paper: ANP, atrial natriuretic peptide; $\mathrm{COX}$, cyclooxygenase; COX-1, constitutive form of COX; COX-2, inducible form of COX; GAPDH, glyceraldehyde-3-phosphate dehydrogenase; GC-MS, gas chromatography-mass spectrometry; NO, nitric oxide; NOS, nitric oxide synthase; SNAP, $S$-nitroso- $N$-acetylpenicillamine; SNP, sodium nitroprusside.

J. Clin. Invest.

(C) The American Society for Clinical Investigation, Inc.

0021-9738/96/05/2051/06 \$2.00

Volume 97, Number 9, May 1996, 2051-2056 ological pathways, including neurotransmission, vasodilation, and inflammation (1-3). NO is synthesized from the guanidino nitrogen of L-arginine by the catalytic reaction of nitric oxide synthase (NOS). The major recognized target of NO action is a hemeprotein, the soluble form of guanylate cyclase, whose activity is increased by binding of NO to the heme moiety of the enzyme (1-3). Increased intracellular cGMP can then modulate cellular functions. $\mathrm{NO}$ also has been found to modulate PG synthesis in macrophage cell lines, rat islet cells of the pancreas, rat uteri, and experimental hydronephrotic kidneys (4-7). It was postulated that NO stimulates cyclooxygenase (COX) activity possibly via the heme component of the COX enzyme, since COX is also a hemeprotein $(8,9)$. However, Tsai et al. (10) have shown that NO does not affect purified ovine COX enzyme activity. Thus, some indirect mechanisms also might be involved in NO-stimulated COX activation and $\mathrm{PGE}_{2}$ formation.

Two isoforms of COX have been cloned and characterized. COX-1 is present in most tissues and constitutively expressed. COX-2 is undetectable under normal physiological conditions in most organs and is expressed after stimulation by various growth factors and cytokines in fibroblasts, macrophages, endothelial cells, and mesangial cells (11-13). We have demonstrated previously that the proinflammatory cytokine, IL-1 $\beta$, induces $\mathrm{COX}-2$ without affecting $\mathrm{COX}-1$ expression and that glucocorticoids suppress IL- $1 \beta$-induced COX-2 protein expression and $\mathrm{PGE}_{2}$ production in rat mesangial cells $(13,14)$. Thus, the changes in COX-2 expression may be one of the major determinants for $\mathrm{PGE}_{2}$ production in IL-1 $\beta$-stimulated mesangial cells.

Intrinsic glomerular endothelial cells and infiltrating macrophages could be a source of cytokines $(15,16)$ and NO $(17-$ 19) in an inflamed glomerulus. In addition, IL-1 and NO are produced by activated mesangial cells (15-19). Thus, during glomerular inflammation, cytokines and NO from glomerular endothelial cells, infiltrating macrophages, and activated mesangial cells may act in concert to sustain and promote glomerular damage. While the induction of COX II and iNOS are separate processes, the potential for significant interaction between these two proinflammatory systems is real. We have provided evidence previously that $\mathrm{PGE}_{2}$ can transcriptionally regulate IL-1 $\beta$-induced iNOS and in this manuscript we have evaluated the effect of NO on the IL-1 $\beta$-induced formation of an inflammatory mediator, $\mathrm{PGE}_{2}$, and $\mathrm{COX}-2$ induction.

\section{Methods}

Materials. Human IL-1 (100 half-maximal units/ng) and restriction enzymes were purchased from Boehringer Mannheim (Indianapolis, $\mathrm{IN})$. Murine cDNA probes ligated in BlueScript $\mathrm{SK}^{-}$for $\mathrm{COX}-1$ (pBS-COX-1) and COX-2 (pBS-COX-2) were generous gifts of Dr. Karen Seibert (Monsanto Company, St. Louis, MO). Sodium nitroprusside (SNP), methylene blue, 9-Br-cGMP, and rat atrial natriuretic peptide (ANP) were from Sigma Immunochemicals (St. Louis, 
MO). $S$-nitroso- $N$-acetylpenicillamine (SNAP) was from Calbiochem-Novabiochem Corp. (La Jolla, CA).

Cell culture. Primary mesangial cell cultures were prepared from male Sprague Dawley rats as described previously (13). Cells were grown in RPMI-1640 medium supplemented with $15 \%$ (vol $/ \mathrm{vol}$ ) heatinactivated fetal calf serum, $0.3 \mathrm{IU} / \mathrm{ml}$ insulin, $100 \mathrm{U} / \mathrm{ml}$ penicillin, 100 $\mu \mathrm{g} / \mathrm{ml}$ streptomycin, $250 \mu \mathrm{g} / \mathrm{ml}$ amphotericin B, and $15 \mathrm{mM}$ Hepes. Cells were used between passages 2 and 6 .

Northern blot analysis. The full-length COX-1 and COX-2 cDNA was excised form the plasmid pBS-COX-1 and pBS-COX-2 as a BamHI-HindIII and KpnI-BamHI digest, respectively. Excised cDNAs were purified from $1 \%$ agarose gels by Gene Clean (BIO 101, Inc., Vista, CA). Rat glyceraldehyde-3-phosphate dehydrogenase (GAPDH) cDNA was prepared by reverse-transcriptase PCR using total RNA of rat mesangial cells as described previously (20). Northern blot analysis was performed as described previously (13). Confluent cells grown in $75-\mathrm{cm}^{2}$ flasks were incubated with IL-1 $\beta$ and/or NO donors in RPMI-1640 media containing 5\% (vol/vol) fetal calf serum for $3 \mathrm{~h}$ and harvested. Total RNA was isolated using the acid guanidium thiocyanate-phenol-chloroform method (RNASTAT $60^{\mathrm{TM}}$; Tel-Test “B," Friendswood, TX). $20 \mu \mathrm{g}$ of total RNA per lane was fractioned by $1 \%$ agarose-formaldehyde gel electrophoresis and transferred onto nylon membranes (Gene-Screen; Du Pont, Boston, MA) in $10 \times \mathrm{SSC}(1 \times \mathrm{SSC}$ is $150 \mathrm{mM} \mathrm{NaCl}$ and $15 \mathrm{mM}$ sodium citrate, $\mathrm{pH}$ 7.0). Membrane filters were dried at $80^{\circ} \mathrm{C}$ for $15 \mathrm{~min}$ and RNA was fixed by cross-linking in a UV Stratalinker-1800 (Stratagene, La Jolla, CA) with 1,200 kJ. Membrane filters were prehybridized for $6 \mathrm{~h}$ at $42^{\circ} \mathrm{C}$ in $50 \%$ deionized formamide (vol/vol), $0.04 \%$ polyvinylpyrrolidone (wt/vol), $0.04 \%$ bovine serum albumin (wt/vol), $0.04 \%$ Ficoll (wt/vol), $5 \times$ SSC, $1 \%$ SDS (wt/vol), and denatured salmon sperm DNA $(100 \mu \mathrm{g} / \mathrm{ml})$. Full-length murine probes for COX-1 and COX-2 were radiolabeled with $\left[{ }^{32} \mathrm{P}\right] \mathrm{dCTP}$ by the random priming method. Hybridization was performed at $42^{\circ} \mathrm{C}$ for $18-20 \mathrm{~h}$ in a solution containing: $50 \%$ deionized formamide ( $\mathrm{vol} / \mathrm{vol}$ ), $0.02 \%$ polyvinylpyrrolidone (wt/vol), $0.02 \%$ bovine serum albumin ( $\mathrm{wt} / \mathrm{vol})$, $0.02 \%$ Ficoll (wt $/ \mathrm{vol}), 5 \times \mathrm{SSC}, 1 \%$ SDS (wt/vol), and denatured salmon sperm DNA $(100 \mu \mathrm{g} / \mathrm{ml})$. Filters were washed twice at room temperature for $5 \mathrm{~min}$ in $2 \times \mathrm{SSC}$ and twice at $60^{\circ} \mathrm{C}$ for $30 \mathrm{~min}$ in $2 \times$ SSC $+0.1 \%(\mathrm{wt} / \mathrm{vol})$ SDS and then exposed overnight to Kodak XAR film at $-70^{\circ} \mathrm{C}$ with intensifying screens. To control for variability in the loaded quantity of RNA, all membranes were probed with GAPDH cDNA to determine the steady state levels of GAPDH gene-related sequences and used to normalize mRNA for COX-1 and COX-2.

Western blot analysis. Confluent cells grown in $75-\mathrm{cm}^{2}$ flasks were incubated in RPMI-1640 containing 5\% (vol/vol) fetal calf serum with IL-1 $\beta$ and/or NO donors for $6 \mathrm{~h}$ (to allow for adequate protein synthesis). Cells were washed twice with ice-cold phosphate-buffered saline, and lysed in $1 \mathrm{ml}$ of ice-cold extraction buffer $(50 \mathrm{mM}$ Tris- $\mathrm{HCl}, \mathrm{pH} 7.4,1 \%$ NP-40, $1 \mathrm{mM}$ EDTA, $1 \mathrm{mM}$ PMSF, $5 \mu \mathrm{g} / \mathrm{ml} \mathrm{leu-}$ peptin, $5 \mu \mathrm{g} / \mathrm{ml}$ pepstatin, $5 \mu \mathrm{g} / \mathrm{ml}$ aprotinin). After $30 \mathrm{~min}$, cells were scraped and centrifuged at $10,000 \mathrm{~g}$ for $10 \mathrm{~min}$ at $4^{\circ} \mathrm{C}$. The supernatant was collected and protein content was determined using a micro bicinchoninic acid assay (Sigma Immunochemicals). Cell lysate was mixed with Laemmli reagent and heated for $10 \mathrm{~min}$. Equal amounts of protein (30-60 $\mu \mathrm{g} / \mathrm{lane})$ was run on 10\% SDS-polyacrylamide gel. Proteins were transferred to polyvinylidene difluoride membranes (Immobilon-P ${ }^{\mathrm{TM}}$; Millipore Corp., Bedford, MA). The membranes were saturated with $5 \%$ fat-free dry milk in Tris-buffered saline (50 $\mathrm{mM}$ Tris, $\mathrm{pH} 8.0,150 \mathrm{mM} \mathrm{NaCl}$ ) with $0.1 \%$ (vol/vol) Tween 20 (TBS$\mathrm{T})$ overnight at $4^{\circ} \mathrm{C}$. The membranes were incubated with purified polyclonal rabbit IgG antibody against murine COX-2 (Cayman Chemical Co., Inc., Ann Arbor, MI) at 1:1,000 dilution in the above solution for $1 \mathrm{~h}$ at room temperature. Blots were washed in TBS-T four times (15 min each). Blots were further incubated for $1 \mathrm{~h}$ at room temperature with the goat anti-rabbit IgG antibody coupled to horseradish peroxidase (Amersham, Arlington Heights, IL) at 1:2,500 dilution in TBS-T. Blots were washed four times (15 min each) in TBS-T before visualization. Enhanced chemiluminescence (ECL) kit (Amersham) was used for detection and exposed to Hyperfilm MP (Amersham).

Measurement of $P G E_{2}$. $\mathrm{PGE}_{2}$ in the media was determined by stable isotope gas chromatography-mass spectrometry (GC-MS) as described previously (13). At the end of predetermined times, medium was removed and spiked with 25-50 ng tetradeuterated $\mathrm{PGE}_{2}$ $\left(\mathrm{d}_{4}-\mathrm{PGE}_{2}\right)$. The medium was then acidified to $\mathrm{pH} 3.5$, and $\mathrm{PGE}_{2}$ was extracted by 1-ml octadecyl columns (Baker Co., Sanford, ME). Extracts were derivatized for GC-MS analysis. The samples were analyzed as the pentafluorobenzyl methoxime trimethylsilyl ether by negative ion chemical ionization using methane as the reagent gas. Ions monitored were $\mathrm{m} / \mathrm{z} 524\left(\mathrm{~d}_{0}-\mathrm{PGE}_{2}\right)$ and $\mathrm{m} / \mathrm{z} 528\left(\mathrm{~d}_{4}-\mathrm{PGE}_{2}\right)$. Mass spectrometry was performed on a Hewlett-Packard $5985^{\mathrm{B}}$ spectrometer using a 25-m Ultra 1 (Hewlett-Packard Co., Palo Alto, CA) capillary column, and data collection and analysis were performed using Vector 2 (Teknivent, St. Louis, MO) software. $\mathrm{PGE}_{2}$ production was normalized for protein as determined by the micro bicinchoninic acid assay.

Statistical analysis. Data were expressed as mean \pm SEM. Statistical analysis was performed by using paired or unpaired Student's $t$ test. A difference with $P$ value $<0.05$ was considered statistically significant.

\section{Results}

$N O$ amplifies $I L-1 \beta$-induced $P G E_{2}$ formation. The effect of the NO donor, SNAP, on $\mathrm{PGE}_{2}$ formation was determined. 0.1$100 \mu \mathrm{M}$ of SNAP by itself did not increase basal $\mathrm{PGE}_{2}$ formation. However, SNAP potentiated IL- $1 \beta$-induced $\mathrm{PGE}_{2}$ production (Fig. $1 A$ ), suggesting that NO potentiates IL-1 $\beta$-induced $\mathrm{PGE}_{2}$ formation. Similarly SNP, itself another NO donor, also potentiated IL-1 $\beta$-induced $\mathrm{PGE}_{2}$ production but not basal $\mathrm{PGE}_{2}$ formation. The stimulatory effect of SNP on IL-1 $\beta-$ induced $\mathrm{PGE}_{2}$ production was maximal at $1-10 \mu \mathrm{M}$ and was attenuated at $100 \mu \mathrm{M}$ (Fig. $1 B$ ).

$N O$ amplifies $I L-1 \beta$-induced $C O X-2$ expression. Since previous observations by us and others suggest that the inducible isoform of $\mathrm{COX}(\mathrm{COX}-2)$ is one of the major determinants of PG production $(13,14,21)$, we evaluated whether NO modulates COX expression. SNAP by itself did not induce COX-2 mRNA. However, SNAP potentiated IL-1 $\beta$-induced COX-2 mRNA (Fig. 2 A). Neither IL- $\beta$ nor SNAP affected COX-1 mRNA expression. Similarly, SNP, another NO donor, also potentiated IL-1 $\beta$-induced COX-2 mRNA expression (Fig. 2 B). To determine whether the increase in COX-2 mRNA leads to an increase in COX-2 protein expression, Western blot analysis was performed. As with COX-2 mRNA expression, SNAP alone did not induce COX-2 protein, but SNAP potentiated IL-1 $\beta-$ induced COX-2 protein expression (Fig. 3, $A$ and $B$ ).

$N O$ amplifies $C O X-2$ expression via cGMP pathway. Endothelium-derived $\mathrm{NO}$ and micromolar range of NO donors, SNAP and SNP, are known to increase cellular cGMP in mesangial cells (22-24). To test the possibility that the NO effect was mediated through the stimulation of the guanylate cyclase and the increase in intracellular cGMP, we examined the effect of an inhibitor of the soluble guanylate cyclase, methylene blue (25), on COX-2 expression. Methylene blue reversed the stimulatory effect of SNAP on IL-1 $\beta$-induced COX-2 mRNA expression (Fig. 4). although methylene blue by itself did not affect basal or IL-1 $\beta$-induced COX-2 mRNA expression (data not shown). To further confirm the effect of cGMP pathway on IL-1 $\beta$-induced COX-2 expression, we tested the effect of a membrane-permeable cGMP analogue, 8-Br-cGMP, and ANP 
A

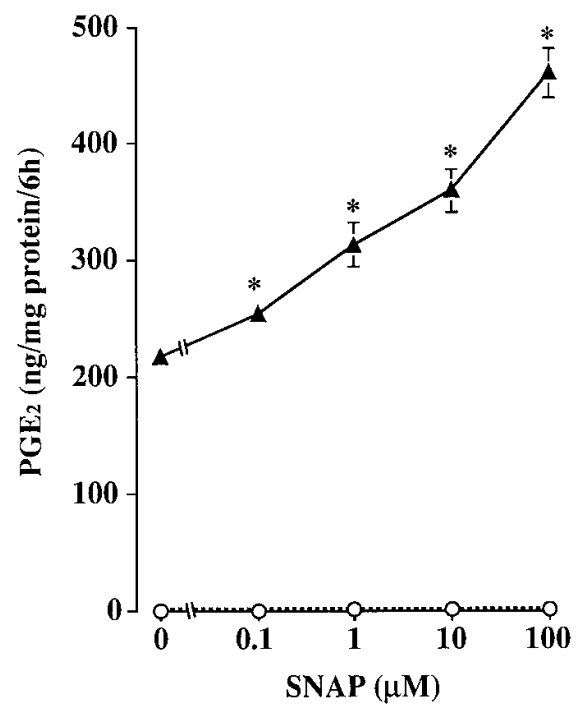

which stimulates membrane-bound guanylate cyclase and increases cellular cGMP in mesangial cells. 8-Br-cGMP by itself did not induce COX-2 mRNA expression and $\mathrm{PGE}_{2}$ formation. However, like NO, 8-Br-cGMP potentiated IL-1 $\beta$-induced $\mathrm{PGE}_{2}$ formation (Fig. $5 \mathrm{~A}$ ) and COX-2 mRNA expression (Fig. 5 B). ANP also amplified IL-1 $\beta$-induced COX-2 mRNA expression, though ANP by itself did not induce COX-2 mRNA (Fig. 6). These data support the notion that cGMP mediates the action of NO and indicates that cGMP can influence COX-2 gene expression.

$N O$ does not affect the COX-2 mRNA stability. Since COX-2 mRNA has the AUUUA motif in its $3^{\prime}$ untranslated region which is considered an mRNA instability determinant (26), either the increase in transcription or the increase in COX-2 mRNA stability might account for the increase in the steady state level of COX-2 mRNA. Therefore, we determined

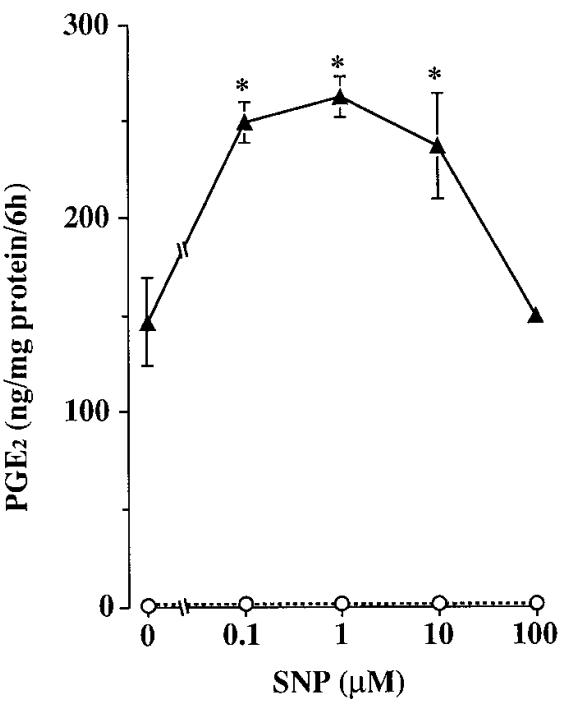

Figure 1. Effect of NO donors on $\mathrm{PGE}_{2}$ production. Cells were stimulated with IL-1 $\beta(50 \mathrm{U} / \mathrm{ml})$ and SNAP $(A)$ or IL-1 $\beta$ and $\operatorname{SNP}(B)$ for $6 \mathrm{~h} . \mathrm{PGE}_{2}$ in the medium was determined by GCMS. $* P<0.05(A$, vs. SNAP 0 $\mu \mathrm{M} ; B$, vs. SNP $0 \mu \mathrm{M})$. Open circles, basal; filled triangles, IL-1. whether NO increases COX-2 mRNA stability. As shown in Fig. 7, SNP did not prolong IL-1 $\beta$-induced COX-2 mRNA half-life. Therefore, changes in mRNA stability do not account for the increase in the steady state level of COX-2 mRNA stimulated by NO.

\section{Discussion}

At the site of glomerular inflammation, infiltrating macrophages and activated mesangial cells may release cytokines and growth factors and may also generate NO and reactive oxygen species (15-19). These stimuli may act in concert to modify the function and morphology of glomerular cells. Thus, in this study we exposed mesangial cells to combinations of NO donors and IL- $1 \beta$, so that mesangial cells received an NO signal simultaneously with a proinflammatory cytokine. The NO
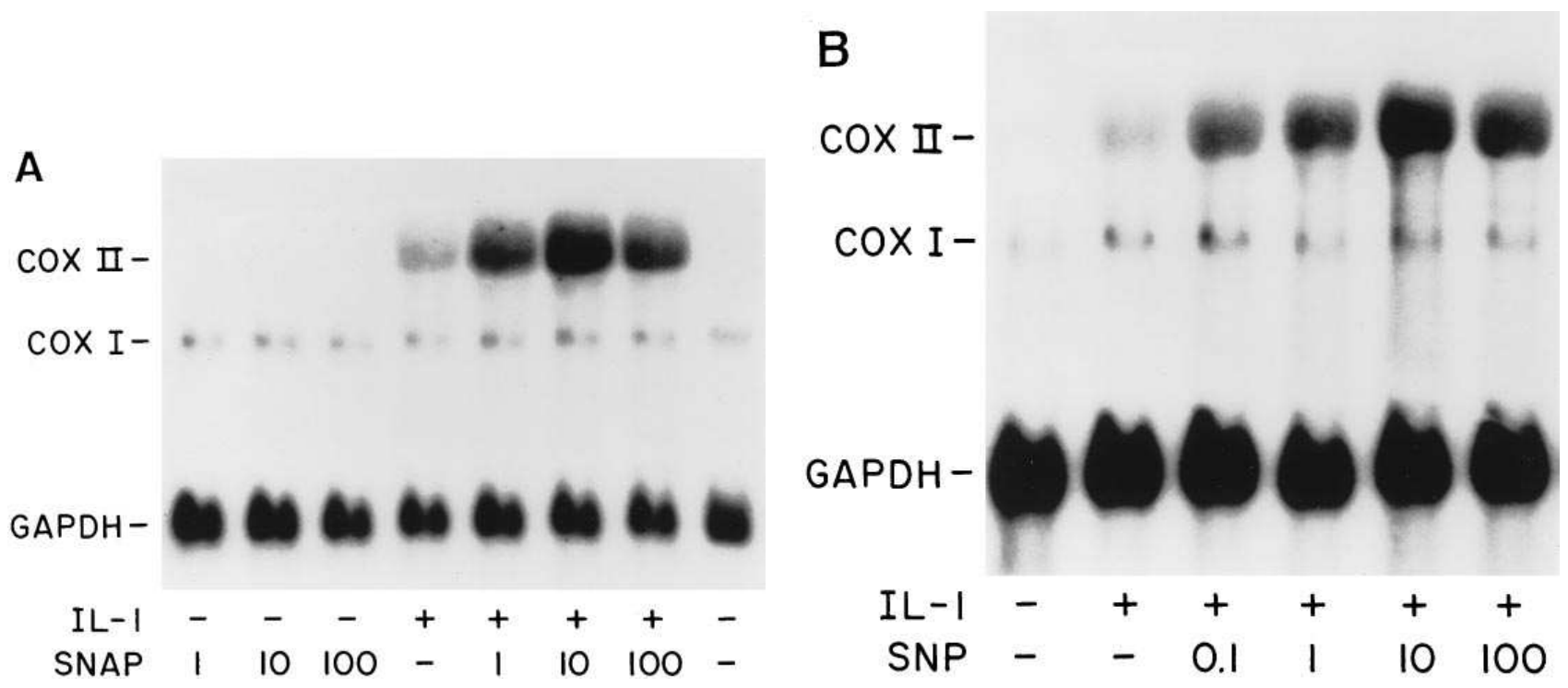

Figure 2. Effect of NO donors on COX-2 mRNA. Cells were stimulated with IL-1 $\beta(50 \mathrm{U} / \mathrm{ml})$ and SNAP $(A)$ or IL-1 $\beta$ and SNP $(B)$ for $3 \mathrm{~h}$ and harvested. $20 \mu \mathrm{g}$ of total RNA was subjected to Northern blot analysis. 

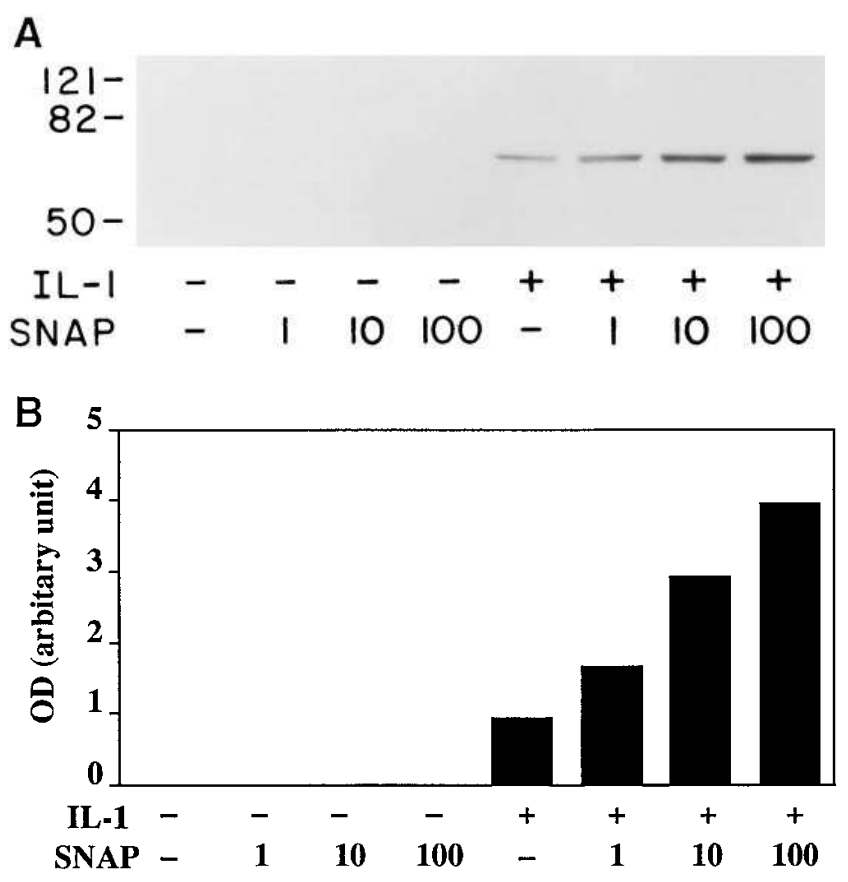

Figure 3. Effect of SNAP on COX-2 protein. $(A)$ Cells were stimulated with IL-1 $\beta(50 \mathrm{U} / \mathrm{ml})$ and/or SNAP $(\mu \mathrm{M})$ for $6 \mathrm{~h}$ and harvested. The protein samples were subjected to Western blot analysis. $(B)$ Quantitation of COX-2 protein. OD was quantified by scanning densitometry.

donors, SNAP and SNP, by themselves did not increase basal $\mathrm{PGE}_{2}$ production and they did not induce COX-2. However, NO donors potentiated IL- $1 \beta$-induced COX- 2 expression and $\mathrm{PGE}_{2}$ formation in a dose-dependent manner. The NO donors used in this study, SNP and SNAP, are known to increase cellular cGMP in rat mesangial cells at micromolar concentrations (22). It was likely that cGMP mediated the action of NO, since $(a)$ an inhibitor for soluble guanylate cyclase, methylene blue, reversed the stimulatory effect of NO donors on COX-2 mRNA expression; $(b)$ the membrane-permeable cGMP analogue, 8-Br-cGMP, dose-dependently mimicked the stimulatory effect of NO on IL- $1 \beta$-induced COX-2 mRNA expression and $\mathrm{PGE}_{2}$ formation; and (c) ANP, which increases cellular cGMP by a receptor-mediated mechanism, also amplified IL-1 $\beta$-induced COX-2 mRNA expression. These data suggest that NO can influence COX-2 gene expression in synergy with IL-1 $\beta$ and that cGMP mediates the action of NO.

Both SNP and SNAP activate the cGMP pathway; however, only the higher dose of SNP attenuated IL-1 $\beta$-induced $\mathrm{PBE}_{2}$ production (Fig. $1 \mathrm{~B}$ ). Since SNP is a ferricyanide compound, and cyanide is known to inhibit COX activity (27), the higher concentrations of SNP might have attenuated COX activity by increased cyanide or thiocyanate accumulation. No gross changes were observed in cell viability as judged by trypan blue exclusion.

In a previous study, we have shown that inhibitors of the NOS enzyme, $N^{\mathrm{G}}$-monomethyl-L-arginine and aminoguanidine, attenuated IL- $1 \beta$-induced $\mathrm{NO}$ and $\mathrm{PGE}_{2}$ production in cultured rat mesangial cells (20). However, $N^{\mathrm{G}}$-monomethylL-arginine and aminoguanidine did not affect IL-1 $\beta$-induced COX-2 protein expression in cultured rat mesangial cells (data not shown). IL-1 $\beta$ rapidly induces COX-2 mRNA in mesan-

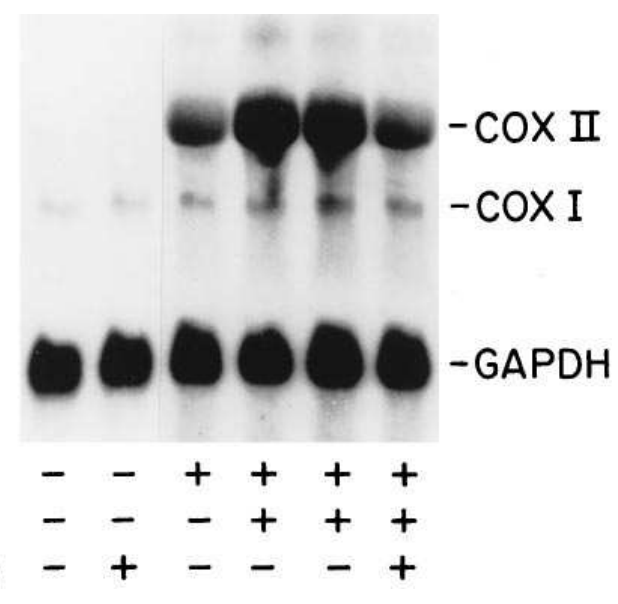

ure 4. Effect on methylene blue on COX-2 mRNA. Cells were preincubated with methylene blue (Meth $B)(10 \mu \mathrm{M})$ for $40 \mathrm{~min}$. Cells were then stimulated with IL-1 $\beta(50 \mathrm{U} / \mathrm{ml})$ and/or SNAP $(10 \mu \mathrm{M})$ for $3 \mathrm{~h}$ and harvested. $20 \mu \mathrm{g}$ of total RNA was used for Northern blot analysis.

gial cells. By Northern blot analysis COX-2 mRNA is detectable at $30 \mathrm{~min}$ after IL-1 $\beta$ stimulation, peaks at $2-3 \mathrm{~h}$, and then gradually declines. The increase in $\mathrm{PGE}_{2}$ production is detectable at $4-6 \mathrm{~h}$. In contrast, IL-1 $\beta$ induces iNOS mRNA more slowly. With Northern blot analysis it is not detectable until $\sim 6 \mathrm{~h}$ after IL-1 $\beta$ stimulation and peaks at $12 \mathrm{~h}$ and then declines. The increase in NO production is not detectable at $6 \mathrm{~h}$ after IL-1 $\beta$ stimulation, and rat mesangial cells do not express neuronal NOS and endothelial NOS (our unpublished observations). Thus, endogenously produced NO by IL- $1 \beta-$ stimulated mesangial cell in culture may not stimulate COX-2 transcription, since the induction of COX-2 mRNA precedes that of iNOS mRNA and NO production. Mesangial cells can simultaneously receive both NO and cytokine signals from infiltrating macrophages and glomerular endothelial cells. When the cells receive NO signals simultaneously with IL- $1 \beta$, NO may increase the transcription of the COX-2 gene via a cGMPmediated mechanism.

COX-2 mRNA has the AUUUA motif in its $3^{\prime}$ untranslated region, which is considered an mRNA instability determinant (26). Thus, either an increase in transcription or an increase in COX-2 mRNA stability might account for the increase in the steady state level of COX-2 mRNA. We have shown previously that IL- $1 \beta$ stabilizes the unstable COX-2 message by phosphorylation of cytosolic factors which bind to AUUUA rich $3^{\prime}$ untranslated region in rat mesangial cells (26). However, changes in mRNA stability are unlikely to account for the amplification of the COX-2 mRNA levels by NO, since NO did not affect the IL-1 $\beta$-induced COX-2 mRNA half-life (Fig. 5). Although we did not further address the molecular mechanism by which NO potentiates IL-1 $\beta-$ induced COX-2 expression, transcription factors, cAMP response element binding protein (CREB) and NFKB, might be among the possible targets of NO. It has been demonstrated that $\mathrm{NO}$ and cGMP amplify $\mathrm{Ca}^{2+}$-induced c-fos expression in PC12 cells via the sequential activation of cAMP-dependent protein kinase, CREB, and cAMP response element (CRE) (28). Although CRE is not identified in the promoter of the rat COX-2 gene (29), the promoters of the mouse and the human COX-2 gene have a CRE adjacent to the TATA box (30-32). 


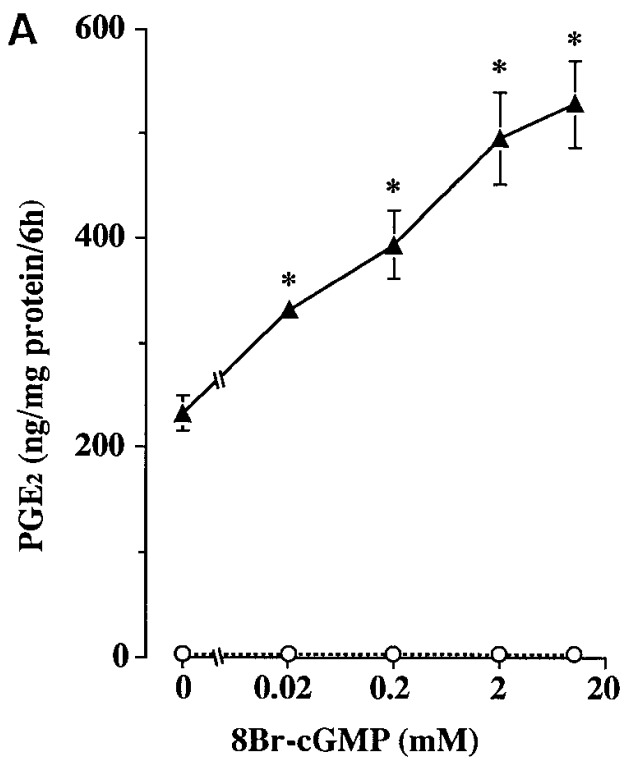

We have demonstrated that the activation of a tyrosine kinase pathway is necessary for IL- $1 \beta$-induced COX-2 mRNA expression (33). Xie et al. (32) have demonstrated that the induction of COX-2 gene stimulated by v-src tyrosine kinase is mediated by CRE in $3 \mathrm{~T} 3$ fibroblasts and that cotransfection of dominant-negative CREB blocks v-src induction of the COX-2 gene. Thus the signals of NO and IL- $1 \beta$ might merge via CREB-CRE- or CREB-CRE-like pathway. NFKB is a critical transcription factor for several genes that are involved in immune and inflammatory responses (34). Stimulation of cells with IL-1, tumor necrosis factor, and lipopolysaccharide leads to the activation of NFkB. Lander et al. (35) have shown that $\mathrm{NO}$ donors activate nuclear translocation of NFKB in human peripheral blood mononuclear cells. The promoter of COX-2 gene has a $\kappa \mathrm{B}$ binding site (29-31) and thus may be activated by $\mathrm{NF}$ B .

NO may synergize not only with signals evoked by IL-1 $\beta$ but also with a variety of stimuli, since NO donors also potentiated COX-2 mRNA expression induced by lipopolysaccharide and by a $\mathrm{Ca}^{2+}$ ionophore, A23187, in rat mesangial cells (data not shown). Although we did not determine the effect of NO on other genes, $\mathrm{NO}$ has been shown to affect the expression of

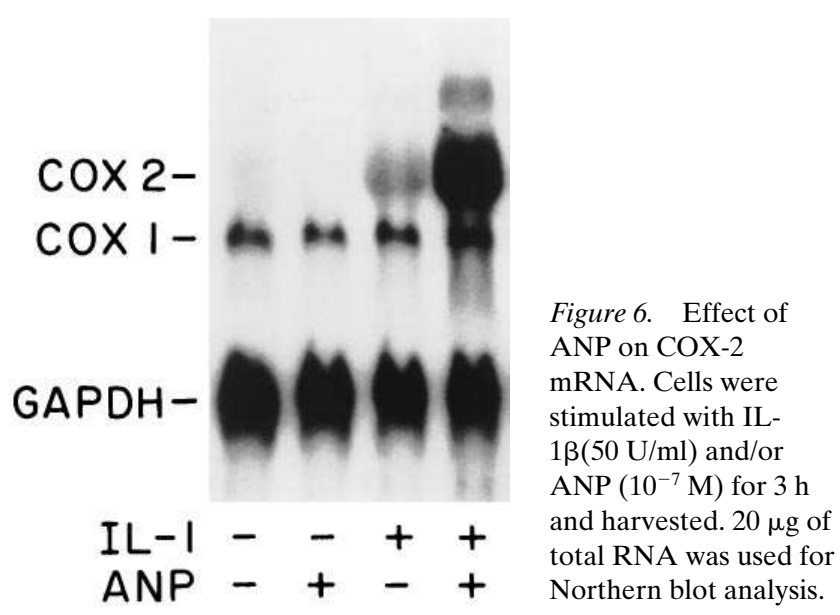

c-fos (28) and iNOS (36). Peunova and Enikolopov (28) have demonstrated that NO amplifies c-fos gene expression stimulated by a $\mathrm{Ca}^{2+}$ signal in PC12 cells. Mühl et al. (36) have shown that NO amplifies IL-1 $\beta$-induced iNOS expression in rat mesangial cells. Thus, when the cells receive NO signals in addition to cytokine-like stimuli, NO may synergize with those

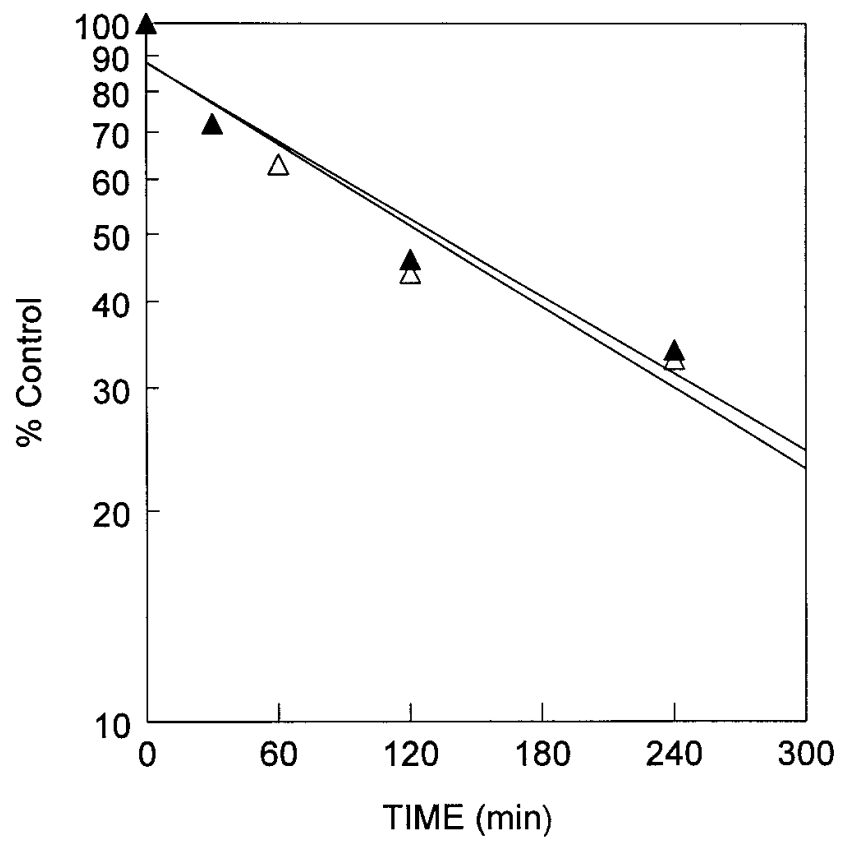

Figure 7. $t_{1 / 2}$ of COX-2 mRNA. Cells were stimulated with IL-1 $\beta$ $(50 \mathrm{U} / \mathrm{ml})$ in the presence or absence of SNP $(10 \mu \mathrm{M})$ for $3 \mathrm{~h}$. Then, actinomycin D $(5 \mu \mathrm{g} / \mathrm{ml})$ was added to stop transcription and the cells were harvested at the different time points $(0,30,60,120$, and 240 $\min$ ). $20 \mu \mathrm{g}$ of total RNA was used for Northern blot analysis. Optical density for COX-2 and GAPDH was quantified by scanning densitometry, and the relative changes ( $\%$ ) in COX-2/GAPDH ratio were plotted. Messages induced by IL-1 $\beta$ alone (filled triangles) and IL-1 $\beta+$ SNP (open triangles) demonstrated identical decay rates, suggesting no significant difference in the $t_{1 / 2}$ of the message. 
stimuli and amplify gene expression including COX-2, iNOS, and c-fos. The effector molecules of these gene product such as PGs, NO, and AP-1 transcription factor, may further mediate subsequent long-term changes in cellular function and gene expression, followed by amplification or attenuation of the inflammatory process. For example, we have demonstrated that the products of $\mathrm{COX}$ pathway, $\mathrm{PGE}_{2}$ and $\mathrm{PGI}_{2}$, have a negative and positive effect on IL-1 $\beta$-induced iNOS mRNA expression, respectively (20). Thus the loop of positive or negative feedback regulation for these proinflammatory genes may work to sustain or terminate inflammation, and products of these genes can be targets for pharmacological intervention during the inflammatory processes.

In summary, we have demonstrated that NO amplifies IL-1 $\beta$-induced COX-2 expression in rat mesangial cells and that this stimulatory action of NO on COX-2 expression appears to be mediated by cGMP. These results indicate a novel interaction of $\mathrm{NO}$ on the COX pathway.

\section{Acknowledgments}

Dr. Tetsuka is a recipient of a National Kidney Foundation matching fellowship. This work was supported by Public Health Service awards HL 20787 and DK PO-38111.

\section{References}

1. Bredt, D.S., and S.H. Snyder. 1994. Nitric oxide. a physiologic messenger molecule. Annu. Rev. Biochem. 63:175-195.

2. Knowles, R.G., and S. Moncada. 1994. Nitric oxide synthase in mammals. Biochem. J. 298:249-258.

3. Moncada, S., R. Palmer, and E. Higgs. 1991. Nitric oxide: physiology, pathophysiology, and pharmacology. Pharmacol. Rev. 43:109-142.

4. Corbett, J.A., G. Kwon, J. Turk, and M.L. McDaniel. 1993. IL-1beta induces the coexpression of both nitric oxide synthase and cyclooxygenase by islets of Langerhans: activation of cyclooxygenase by nitric oxide. Biochemistry. 32:13767-13770.

5. Franchi, A.M., M. Chaud, V. Rettori, A. Suburo, S.M. McCann, and M. Gimeno. 1994. Role of nitric oxide in eicosanoid synthesis and uterine motility in estrogen-treated rat uteri. Proc. Natl. Acad. Sci. USA. 91:539-543.

6. Salvemini, D., T.P. Misko, J.L. Masferrer, K. Seibert, M.G. Curie, and P. Needleman. 1993. Nitric oxide activates cyclooxygenase enzyme. Proc. Natl. Acad. Sci. USA. 90:7240-7244.

7. Salvemini, D., K. Seibert, J.L. Masferrer, T.P. Misko, M.G. Currie, and P. Needleman. 1994. Endogenous nitric oxide enhances prostaglandin production in a model of renal inflammation. J. Clin. Invest. 93:1940-1947.

8. DeWitt, D.L., E.A. el-Harith, S.A. Kraemer, M.J. Andrews, E.F. Yao, R.L. Armstrong, and W.L. Smith. 1990. The aspirin and heme-binding sites of ovine and murine prostaglandin endoperoxide synthases. J. Biol. Chem. 265: 5192-5198.

9. Shimokawa, T., and W.L. Smith. 1991. Essential histidines of prostaglandin endoperoxide synthase. His-309 is involved in heme binding. J. Biol. Chem. 266:6168-6173.

10. Tsai, A.L., C. Wei, and R.J. Kulmacz. 1994. Interaction between nitric oxide and prostaglandin H synthase. Arch. Biochem. Biophys. 313:367-372.

11. Baird, N.R., and A.R. Morrison. 1993. Amplification of the arachidonic acid cascade: implications for pharmacologic intervention. Am. J. Kidney Dis. 21:557-564.

12. Kujubu, D.A., B.S. Fletcher, B.C. Varnum, R.W. Lim, and H.R. Herschman. 1991. TIS10, a phorbol ester tumor promoter-inducible mRNA from Swiss 3 T3 cells, encodes a novel prostaglandin synthase/cyclooxygenase homologue. J. Biol. Chem. 266:12866-12872.

13. Rzymkiewicz, D., K. Leingang, N. Baird, and A.R. Morrison. 1994. Reg- ulation of prostaglandin endoperoxide synthase gene expression in rat mesangial cells by interleukin-1 beta. Am. J. Physiol. 266 (Renal Fluid Electrolyte Physiol. 35):F39-F45.

14. Coyne, D.W., M. Nickols, W. Bertrand, and A.R. Morrison. 1992. Regulation of mesangial cell cyclooxygenase synthesis by cytokines and glucocorticoids. Am. J. Physiol. 263 (Renal Fluid Electrolyte Physiol. 32):F97-F102.

15. Sedor, J.R., Y. Nakazato, and M. Konieczkowski. 1992. Interleukin-1 and the mesangial cell. Kidney Int. 41:595-599.

16. Sedor, J.R. 1992. Cytokines and growth factors in renal injury. Seminars in Nephrology. 12:428-440.

17. Cattel, V., and H.T. Cook. 1993. Nitric oxide: role in the physiology and pathology of the glomerulus. Exp. Nephrol. 1:36-40.

18. Pfeilschifter, J., D. Kuntz, and H. Mühl. 1993. Nitric oxide: an inflammatory mediator of glomerular mesangial cells. Nephron. 64:518-525.

19. Raij, L., and P.J. Shults. 1992. Endothelium-derived relaxing factor, nitric oxide: effects on and production by mesangial cells and the glomerulus. $J$. Am. Soc. Nephrol. 3:1435-1441.

20. Tetsuka, T., D. Daphna-Iken, S.K.Srivastave, L.D. Baier, J. DuMain, and A.R. Morrison. 1994. Cross-talk between cyclooxygenase and nitric oxide pathways: prostaglandin E2 negatively modulates induction of nitric oxide synthase by interleukin-1. Proc. Natl. Acad. Sci. USA. 91:12168-12172.

21. Reddy, S.T., and H.R. Hershman. 1994. Ligand-induced prostaglandin synthesis requires expression of the TIS10/PGS-2 prostaglandin synthase gene in murine fibroblasts and macrophages. J. Biol. Chem. 269:15473-15480.

22. Garg, U.C., and A. Hassid. 1989. Inhibition of rat mesangial cell mitogenesis by nitric oxide-generating vasodilators. Am. J. Physiol. 257:F60-F66.

23. Marsden, P.A., T.A. Brock, and B.J. Ballermann. 1990. Glomerular endothelial cells respond to calcium-mobilizing agonists with release of EDRF. Am. J. Physiol. 258:F1295-F1303.

24. Shultz, P.J., A.E. Schorer, and L. Raij. 1990. Effects of endotheliumderived relaxing factor and nitric oxide on rat mesangial cells. Am. J. Physiol. 258:F162-F167.

25. Gruetter, C.A., B.K. Barry, D.B. McNamara, D.Y. Gruetter, P. Kadowitz, and L. Ignarro. 1979. Relaxation of bovine coronary artery and activation of coronary arterial guanylate cyclase by nitric oxide, nitroprusside and a carcinogenic nitrosoamine. J. Cyclic Nucleotide Res. 5:211-224.

26. Srivastava, S.K., T. Tetsuka, D. Daphna-Iken, and A.R. Morrison. 1994. IL-1 beta stabilized COX II mRNA in renal mesangial cells: role of 3' untranslated region. Am. J. Physiol. 267 (Renal Fluid Electrolyte Physiol. 36):F504-F508.

27. Kulmacz, R.J., and W.E.M. Lands. 1985. Quantitative similarities in the several actions of cyanide on prostaglandin H synthase. Prostaglandins. 29:175190.

28. Peunova, N., and G. Enikolopov. 1993. Amplification of calciuminduced gene transcription by nitric oxide in neuronal cells [published erratum appears in Nature (Lond.). 1993. Sept. 30;365:468]. Nature (Lond.). 364:450453.

29. Sirois, J., L.O. Levy, D.L. Simmons, and J.S. Richards. 1993. Characterization and hormonal regulation of the promoter of the rat prostaglandin endoperoxide synthase 2 gene in granulosa cells. Identification of functional and protein-binding regions. J. Biol. Chem. 268:12199-12206.

30. Fletcher, B.S., D.A. Kujubu, D.M. Perrin, and H.R. Herschman. 1992. Structure of the mitogen-inducible TIS10 gene and demonstration that the TIS10-encoded protein is a functional prostaglandin $\mathrm{G} / \mathrm{H}$ synthase. J. Biol. Chem. 267:4338-4344.

31. Kosaka, T., A. Miyata, H. Ihara, S. Hara, T. Sugimoto, O. Takeda, E. Takahashi, and T. Tanabe. 1994. Characterization of the human gene (PTGS2) encoding prostaglandin-endoperoxide synthase 2. Eur. J. Biochem. 221:889897.

32. Xie, W., B.S. Fletcher, R.D. Andersen, and H.R. Herschman. 1994. v-src induction of the TIS10/PGS2 prostaglandin synthase gene is mediated by an ATF/CRE transcription response element. Mol. Cell. Biol. 14:6531-6539.

33. Rzymkiewicz, D.M., J. DuMaine, and A.R. Morrison. 1995. IL-1 beta regulates rat mesangial cyclooxygenase II gene expression by tyrosine phosphorylation. Kidney Int. 47:1354-1363.

34. Baeuerle, P.A., and T. Henkel. 1994. Function and activation of NF-kB in the immune system. Annu. Rev. Immunol. 12:141-179.

35. Lander, H.M., P. Sehajpal, D.M. Levine, and A. Novogrodsky. 1993. Activation of human peripheral blood mononuclear cells by nitric oxide-generating compounds J. Immunol. 150:1509-1516.

36. Mühl, H., and J. Pfeilschifter. 1995. Amplification of nitric oxide synthase expression by nitric oxide in interleukin $1 \beta$-stimulated rat mesangial cells. J. Clin. Invest. 95:1941-1946. 